\title{
The reuse of peanut organic wastes as a growth medium for ornamental plants
}

\author{
A. Mohammadi Torkashvand ${ }^{1} \cdot$ M. Alidoust $^{1} \cdot$ A. Mahboub Khomami ${ }^{2}$
}

Received: 16 January 2014 / Accepted: 26 February 2015/Published online: 19 March 2015

(C) The Author(s) 2015. This article is published with open access at Springerlink.com

\begin{abstract}
Background The reuse of organic wastes in agriculture is an appropriate method of environment management. Most plants with ornamental leaves are cultivated in soilless media, in which peat is the basic medium; but the use of peat is questionable due to ecological damage to the environment and economic disadvantages to ornamental plant producers. Peanut shells as remained wastes of cultivating peanut has a considerable volume, compost of which can be used as available sources of ornamental plants medium. A pot experiment was conducted to investigate the possibility of using peanut shell compost in the appropriate bed in the cultivation of ornamental plants. Dracaena marginata was selected as the test plant. The control treatment consisted of a 2:1 ratio of peat to perlite, and peat was replaced by $15,30,45,60$ and $100 \% \mathrm{v} / \mathrm{v}$ of peanut shell compost. The study was done based on a complete randomized design in three repetitions in the ornamental plants and flowers research station, Lahijan, Iran.

Results The results showed that the bulk density of the planting beds decreased with the addition of peanut shell compost in comparison to the control. Peanut shell compost increased total nitrogen and available phosphorus and potassium of the media. Peanut shell compost increased plant growth indices, but the growth was reduced in $100 \%$
\end{abstract}

A. Mohammadi Torkashvand

m.torkashvand54@yahoo.com; torkashvand@iaurasht.ac.ir

1 Department of Horticulture, Faculty of Agriculture, Islamic Azad University, Rasht Branch, Rasht, Iran

2 Ornamental Plants and Flowers Research Station, Lahijan, Iran in the compost treatment. The compost led to increase in nutrient uptake by plants.

Conclusion In conclusion, it became known that peanut shell compost is an appropriate alternative to peat as the growth medium of ornamental plants. Because of the favorable properties and high porosity, peanut shell compost can be mixed with low-porosity substrates and applied as a substitute to peat in the cultivation media. It is not suggested to increase peanut compost level by 60 and $100 \%$.

Keywords Compost - Dracaena - Environment . Nutrient $\cdot$ Peat $\cdot$ Perlite $\cdot$ Soilless

\section{Introduction}

The cultivation of peanut is common in several populous countries, in which it is a major food crop. According to the World Food and Agriculture Organization, the major peanut producing countries are India, China, USA, Indonesia and Myanmar. Peanut cultivation worldwide covers about 22.2 million hectares, comprising 16.3 million hectares in Asia, 7.39 million hectares in Africa and 0.7 million hectares in South and Central America (Maiti and Ebeling 2002; Murata 2003). The average yield of pods on a global scale increased from 1980 to 2003. Although the highest yield, 9.6 tons per hectare, has been reported in many countries, the yields are usually 3-4 ton/ha. Technology, proper crop management, soil conditions and climate fluctuations are the factors that directly affect the yield of peanut (Maiti and Ebeling 2002).

The cultivated area of peanut in Iran is about 3218, 2718 ha of which is located in the Guilan Province. About $1980-3500 \mathrm{~kg} / \mathrm{ha}$ pods is harvested and 89327.6 tons produced in Guilan. The average shell wastes of $1 \mathrm{~kg}$ yield is 
35-40\%; therefore, about 3388-3873 tons of peanut shells wastes are annually produced in Iran (Agriculture Organization of Guilan Province 2010). As a result, it has been decided to evaluate the possibility of using this organic waste as a growth medium for Dracaena marginata as a test plant.

Today, most plants with ornamental leaves are cultivated in soilless media, among which peat is a basic medium (Atieyh et al. 2000). However, the use of peat causes ecological damage to the environment and economic disadvantages to ornamental plant producers. These factors caused researchers to use beds of high quality and low expense, instead of peat (Krumfolz et al. 2000).

Millions of tons of different agricultural wastes are produced annually across the country, but unfortunately a major fraction is burned or left unattended, leading to environmental pollution (Mohammadi Torkashvand 2010). With increasing awareness of environmental problems of wastes and to decrease the use of non-renewable sources such as peat, further use of composted biosolids has been suggested in farming (Bugbee 2002; Papafotiou et al. 2005). However, in recent years, the wastes have been chemically or biologically treated to obtain useful products before the final disposal (Rajesh Banu et al. 2001, 2007).

Some studies show that peat can be replaced by organic wastes such as municipal wastes, sewage sludge, livestock manure, paper, waste from pruning, and fungi beds and other organic waste after composting (Gayasinghe et al. 2010). Investigations of Ficus benjamina variety Starlight in a growth medium containing a ratio of $1: 1$ of peat to olive waste (as volume) showed the plant growth to be very high during 10 months (Chen et al. 1989). Papafotiou et al. (2005) used olive waste compost as an alternative to peat to cultivate some ornamental plants and suggested that 25,75 and $75 \% \mathrm{v} / \mathrm{v}$ of this compost could be used for cultivating Ficus benjamina, Cordyline and Syngonium podophyllum, respectively.

Applications of manure, wood chips and paper wastes mixed with volcanic material in the cultivation bed of croton (Codiaeum variegatum) and chrysanthemum showed that these materials can be used as planting beds (Cull 1981). The bark of broad leaves and conifer trees, sewage sludge, sawdust, mushroom compost and municipal waste compost are other materials that can be used as planting beds (Fred et al. 1997; Scharpenseel and Kunth 1987; Verdonck and Gabriels 1992). The aim of this study is to evaluate the possibility of using cellulose waste compost of peanuts (shells) as a growth medium for Dracaena.

\section{Methods}

This experiment was conducted at the Ornamental Plants and Flower Research Center, Lahijan, Iran, to evaluate the impacts of composted peanut shell wastes as an alternative to peat on the growth medium for ornamental plants. The peanut shells were supplied by a peeling peanut factory located in Astane Ashrafie Township, Guilan, Iran, and transferred to the research station. Peanut shells were placed in $1 \mathrm{M}^{3}$ wooden boxes (Fig. 1) that had pores to provide aerobic conditions and ensure the activity of microorganisms. The temperatures and aerations were recorded during 4 months and the prepared compost was applied as the growth medium. Some physical and chemical characteristics of peanut shells (total nitrogen, phosphorus, potassium, organic carbon, $\mathrm{C} / \mathrm{N}$ ratio, $\mathrm{EC}$ and $\mathrm{pH}$ in 1:5 extract peanut shells to water) before and after composting were measured (Table 1).

D. marginata was selected as the test plant. It is a perennial plant with evergreen, shiny and smooth leaves and often has a cluster makeup at the end. It has green leaves with a dominant red color in the periphery and ivory-colored stripes at the central parts. These species have lower chlorophyll than typical green species (Edwards 1999). The peanut shell compost was produced and passed through a $20 \mathrm{~mm}$ sieve. Some physical and chemical characteristics (total nitrogen, phosphorus, potassium, organic carbon, $\mathrm{C} / \mathrm{N}$ ratio, $\mathrm{EC}$ and $\mathrm{pH}$ in 1:5 extract peanut shells to water) were measured (Table 1). A factorial completely randomized design was used with two factors including (a) growth media with different levels of peanut shell compost and (b) nutrient solution.

Factor $A$ six treatments of the growth medium are as follows:

1. Control: medium with a ratio $2: 1 \mathrm{v} / \mathrm{v}$ of peat to perlite,

2. $15 \%$ compost: peat was replaced by $15 \mathrm{v} / \mathrm{v}$ of peanut shell compost in the medium,

3. $30 \%$ compost: peat was replaced by $30 \mathrm{v} / \mathrm{v}$ of peanut shell compost in the medium,

4. $45 \%$ compost: peat was replaced by $45 \mathrm{v} / \mathrm{v}$ of peanut shell compost in the medium,

5. $60 \%$ compost: peat was replaced by $60 \mathrm{v} / \mathrm{v}$ of peanut shell compost in the medium,

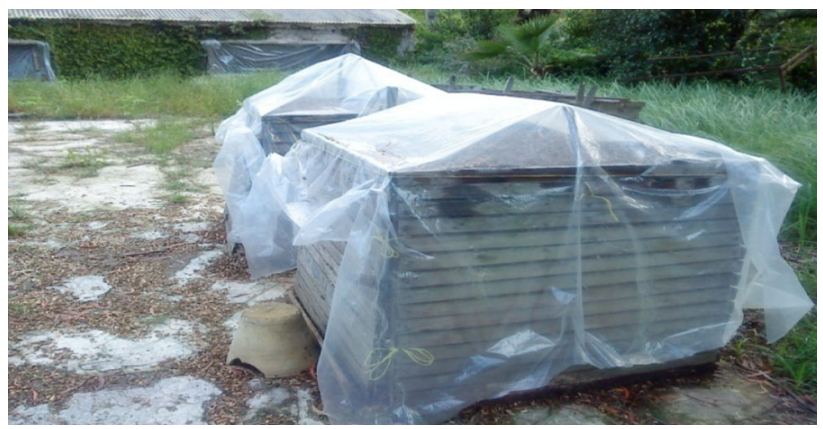

Fig. 1 The applied box for providing peanut shell compost 
Table 1 Some properties of composted peanut shells and peat used in the experiment

\begin{tabular}{llll}
\hline Property & $\begin{array}{l}\text { Peanut } \\
\text { shell wastes }\end{array}$ & $\begin{array}{l}\text { Composted } \\
\text { peanut shells }\end{array}$ & Peat \\
\hline Total nitrogen (\%) & 0.87 & 2.76 & 0.63 \\
Total phosphorus (\%) & 1.87 & 0.67 & 0.03 \\
Total potassium (\%) & 1.19 & 1.48 & 0.03 \\
Organic carbon (\%) & 30.0 & 27.1 & 55.7 \\
C/N ratio & 34.5 & 9.8 & 88.5 \\
pH (1:5) & 5.89 & 5.06 & 4.62 \\
EC (dS/m) & 1.38 & 4.30 & 0.32 \\
\hline
\end{tabular}

6. $100 \%$ compost: peat was replaced by $100 \mathrm{v} / \mathrm{v}$ of peanut shell compost in the medium.

Factor $B$

1. With the use of nutrient solution,

2. Without the use of nutrient solution.

Therefore, 12 treatments in three replications were used in this study. The applied peat was purchased from the SAB Company in Germany. After preparing the media, the rooted cutting of $D$. marginata was transferred to pots. For this aim, first after preparing the beds, the roots of $D$. marginata were removed from the transplant pot and completely washed. Then for each pot with a new bed, one plant was cultivated and then transferred to the greenhouse to pass the plant growth period. Plant height and crown diameter, dry weights of the leaves and roots and fresh weights of the leaves and roots were measured at the end of the experiment.

The total Kjeldahl nitrogen (TKN) and the total organic carbon (TOC) of the samples were estimated using a micro-Kjeldahl method (Singh and Pradhan 1981) and Walkey and Blacks (1934) rapid titration method, respectively. The $\mathrm{pH}$ and EC were determined on an extract of 1:5 ratio of compost to water by weight. Phosphorus and potassium were determined by spectrophotometric and flame photometric methods, respectively. The physical properties of beds were measured by Gabriels et al. (1993).

During the growth period, the pots were irrigated with distilled water. The leaves were harvested after 4 months and the dry matter yield was determined after drying of the harvested leaves at $70{ }^{\circ} \mathrm{C}$ for $48 \mathrm{~h}$. Subsamples of the dry leaves were ground and then the dry ash was extracted with $2 \mathrm{M} \mathrm{HCl}$ from the furnace at $550{ }^{\circ} \mathrm{C}$. The concentrations of $\mathrm{Ca}, \mathrm{Mg}, \mathrm{Fe}, \mathrm{Mn}$ and $\mathrm{Zn}$ were measured in the extracts by atomic absorption spectrophotometry, $\mathrm{K}$ by flame photometry, and $\mathrm{P}$ by spectrophotometry. The experiment was a completely randomized design in three replications and MSTATC software was used for the variance analysis of data by least significant difference (LSD) test.

\section{Results}

\section{Physical and chemical characteristics of the cultivation media}

Some physical and chemical characteristics of the planting media are provided in Table 2 . The use of peanut shell compost tends to decrease the bulk density of the growth media. The highest decrease was observed in $100 \%$ compost; consequently, the porosity of this medium increased by $2 \%$ more than that of the control. The $\mathrm{C} / \mathrm{N}$ ratios in the peanut shell compost treatments were much lower than in the control due to the high organic carbon and low total nitrogen in peat compounds. The use of peanut shell compost caused a decrease in the available phosphorus of cultivation beds. A noticeable aspect was an increase in potassium in the cultivation beds in proportion to the used peanut shell compost. Potassium in $100 \%$ perlite treatment was 40 times more than that of the control treatment, but it should be noted that the salinity of the bed increased from $0.21 \mathrm{dS} / \mathrm{m}$ in the control to $4.38 \mathrm{dS} / \mathrm{m}$ in the $100 \%$ perlite treatment. Acidity $(\mathrm{pH})$ increased in proportion to the compost used, so $\mathrm{pH}$ increased by 1.18 units in the $100 \%$ compost treatment compared with that in the control.

\section{Impacts of treatments on plant growth}

ANOVA results (Table 3 ) showed that the effect of compost (A) on all indices of growth and the impact of nutrient solution (B) on the growth indices of plants (except the dry weight of root) were significant at a $5 \%$ level. The interaction impact $\mathrm{A} \times \mathrm{B}$ was significant at a $5 \%$ level in terms of leaf numbers, height, crown diameter and the fresh and dry weight of leaves.

Table 4 indicates the impact of treatments on the growth of plants. The highest recorded leaf number was observed at 15,30 and $60 \%$ compost, respectively. The highest plant height $(23.61 \mathrm{~cm})$ was obtained for the $15 \%$ treatment of peanut shell compost, which had no significant difference from the $30 \%$ treatment with peanut shell compost $(22.67 \mathrm{~cm})$. However, there was a significant difference in the control $(19.11 \mathrm{~cm})$. The lowest height $(11.67 \mathrm{~cm})$ was related to $100 \%$ peanut shell compost. The largest crown diameter $(2.36 \mathrm{~cm})$ was found for the $30 \%$ peanut shell compost, a more significant difference than that found for the control. All peanut shell compost treatments caused an increase in crown diameter compared to the control. The largest dry weight of root (8.29 g) was obtained in $45 \%$ peanut shell compost, which differed significantly from that of the control $(2.25 \mathrm{~g})$, but showed no difference from 15,30 and $60 \%$ compost. The lowest dry weight of root $(5.77 \mathrm{~g})$ was related to $100 \%$ peanut shell compost. The treatments of peanut shell compost 


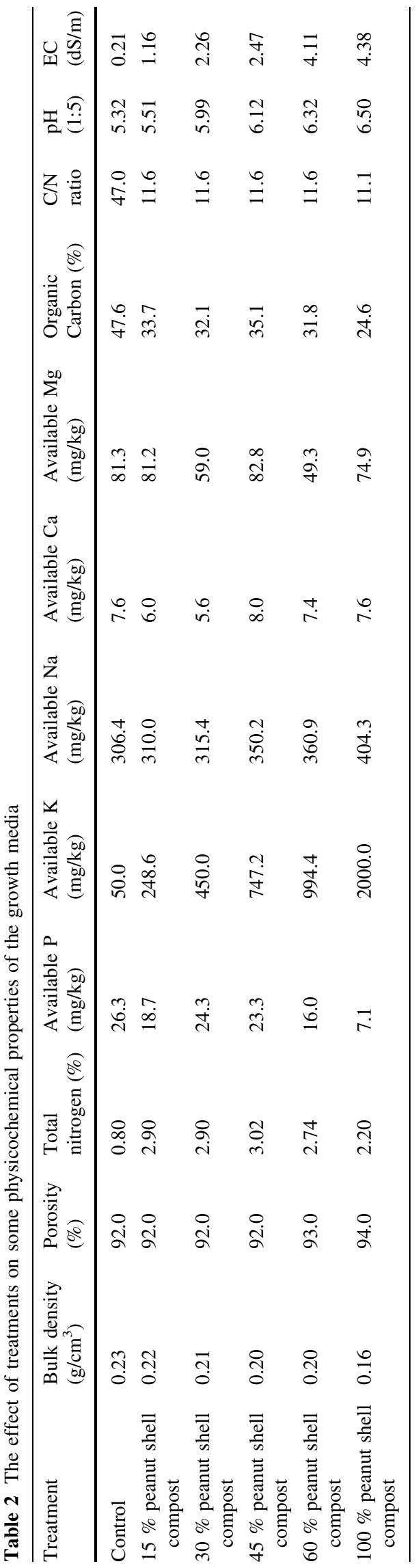

significantly increased the leaf dry weight, more than in the control; however, the lowest leaf dry weight (4.02 g) obtained in $100 \%$ peanut shell compost was significantly lower than that of the control.

Table 5 shows that the nutrient solutions had a further impact on the growth of plants in all treatments, compared to plants receiving no nutrient solution. Based on Table 6, the highest plant height $(26.0 \mathrm{~cm})$ was obtained for $15 \%$ peanut shell compost with a nutrient solution. This differed significantly from the control $(13.0 \mathrm{~cm})$ without a nutrient solution. The comparison between the control treatments, the nutrient solution and compost treatments without a nutrient solution indicated that the growth indices of the control treatment were approximately the same with compost treatment and without a nutrient solution.

\section{Impacts of treatments on nutrient concentration in leaves}

Based on Table 7, the effect of compost (A) on the concentration of N, P, Ca, Mg, Fe, $\mathrm{Zn}$ and $\mathrm{Mn}$ in leaves and the impact of nutrient solution (B) on $\mathrm{P}, \mathrm{K}, \mathrm{Fe}$ and $\mathrm{Mn}$ were significant at a $5 \%$ level. The interaction impact $\mathrm{A} \times \mathrm{B}$ was significant at all nutrient concentrations (excluding $\mathrm{N}$ ) at a $5 \%$ level. The concentration of $\mathrm{P}, \mathrm{Mg}$ and $\mathrm{Mn}$ in leaves decreased in treatments with peanut shell compost (Table 8). Nitrogen concentration increased in $15 \%$ compost treatments and then decreased in other treatments of compost, so they showed no significant difference from the control.

Nutrient solution significantly increased the phosphorus and potassium and decreased the zinc and manganese concentrations in leaves, compared to leaves without a nutrient solution (Table 5). The interaction impact $\mathrm{A} \times \mathrm{B}$ on the nutrient concentration in Dracaena leaves is provided in Table 9. The results show that the highest leaf nitrogen $(2.74 \%)$ was related to a $15 \%$ peanut shell compost treatment with a nutrient solution, which differed significantly from $0,30,45,60$ and $100 \%$ treatments in both nutrition conditions. The control treatment had a higher concentration of phosphorus $(2.13 \%)$ than the 15 , 30,45 and $60 \%$ treatments of peanut shell compost. The lowest phosphorus concentration was observed for the $45 \%$ peanut shell compost without a nutrient solution. The highest $\mathrm{K}$ concentration was observed for the $30 \%$ shell compost with a nutrient solution. The impact of peanut shell compost was significant on leaf calcium. The highest calcium $(8.74 \%)$ was observed for the $30 \%$ peanut shell compost with a nutrient solution, a significant difference from the other treatments.

Based on Table 7, the effect of compost (A) on the uptake of all nutrients by plants and the impact of nutrient solution (B) on $\mathrm{N}, \mathrm{P}, \mathrm{K}, \mathrm{Ca}, \mathrm{Mg}, \mathrm{Fe}$ and $\mathrm{Mn}$ were 
Table 3 The ANOVA results of the treatment effect on growth of Dracaena marginata

\begin{tabular}{|c|c|c|c|c|c|c|c|c|c|c|}
\hline \multirow{2}{*}{$\begin{array}{l}\text { Variation } \\
\text { Resources }\end{array}$} & \multirow{2}{*}{$\begin{array}{l}\text { Freedom } \\
\text { Degree }\end{array}$} & \multicolumn{9}{|c|}{ Mean squared } \\
\hline & & $\begin{array}{l}\text { Leaf } \\
\text { number }\end{array}$ & Height & $\begin{array}{l}\text { Crown } \\
\text { diameter }\end{array}$ & $\begin{array}{l}\text { Fresh } \\
\text { weight } \\
\text { of root }\end{array}$ & $\begin{array}{l}\text { Dry weight } \\
\text { of root }\end{array}$ & $\begin{array}{l}\text { Fresh weight } \\
\text { of stem }\end{array}$ & $\begin{array}{l}\text { Dry weight } \\
\text { of stem }\end{array}$ & $\begin{array}{l}\text { Fresh } \\
\text { weight } \\
\text { of leaf }\end{array}$ & $\begin{array}{l}\text { Dry weight } \\
\text { of leaf }\end{array}$ \\
\hline A: compost & 5 & $86.4 *$ & $108.3 *$ & $1.10^{*}$ & $723.0^{*}$ & $7.63^{*}$ & $98.0 *$ & $3.87 *$ & $347.6^{*}$ & $16.5^{*}$ \\
\hline B: nutrient solution & 1 & $2131.0^{*}$ & $285.4 *$ & $3.82 *$ & $887.6^{*}$ & $11.3^{\mathrm{ns}}$ & $500.5^{*}$ & $14.2^{*}$ & $3108.6^{*}$ & $65.0 *$ \\
\hline $\mathrm{A} \times \mathrm{B}$ & 5 & $77.6^{*}$ & $19.5^{*}$ & $0.87 *$ & $245.9^{\text {ns }}$ & $2.19^{\mathrm{ns}}$ & $19.3^{\mathrm{ns}}$ & $0.15^{\mathrm{ns}}$ & $82.9 *$ & $6.34 *$ \\
\hline Error & 24 & 296.7 & 2.59 & 0.28 & 104.3 & 2.57 & 198.8 & 13.5 & 28.3 & 2.30 \\
\hline
\end{tabular}

* significant at $5 \%$ level

ns not significant at $5 \%$ level

Table 4 The effect of treatments on the growth of Dracaena marginata

\begin{tabular}{|c|c|c|c|c|c|c|c|c|c|}
\hline Treatment & $\begin{array}{l}\text { Leaf } \\
\text { Number }\end{array}$ & $\begin{array}{l}\text { Height } \\
(\mathrm{cm})\end{array}$ & $\begin{array}{l}\text { Crown } \\
\text { diameter } \\
(\mathrm{cm})\end{array}$ & $\begin{array}{l}\text { Fresh } \\
\text { weight } \\
\text { of leaf }(\mathrm{g})\end{array}$ & $\begin{array}{l}\text { Dry } \\
\text { weight } \\
\text { of leaf }(g)\end{array}$ & $\begin{array}{l}\text { Fresh } \\
\text { weight } \\
\text { of stem }(\mathrm{g})\end{array}$ & $\begin{array}{l}\text { Dry } \\
\text { weight } \\
\text { of stem }(\mathrm{g})\end{array}$ & $\begin{array}{l}\text { Fresh } \\
\text { weight } \\
\text { of root }(\mathrm{g})\end{array}$ & $\begin{array}{l}\text { Dry } \\
\text { weight } \\
\text { of root }(\mathrm{g})\end{array}$ \\
\hline Control & $21 \mathrm{~cd}$ & $19.1 \mathrm{bc}$ & $1.33 \mathrm{c}$ & $33.0 \mathrm{~b}$ & $4.75 \mathrm{~cd}$ & $13.1 \mathrm{bc}$ & $2.25 \mathrm{~cd}$ & $47.2 \mathrm{c}$ & $5.80 \mathrm{~b}$ \\
\hline $15 \%$ peanut shell compost & $26 a b$ & $23.6 \mathrm{a}$ & $2.33 \mathrm{a}$ & $41.8 \mathrm{a}$ & $6.62 \mathrm{~b}$ & $18.0 \mathrm{a}$ & $3.66 \mathrm{a}$ & $62.9 \mathrm{ab}$ & $7.42 \mathrm{ab}$ \\
\hline $30 \%$ peanut shell compost & $27 \mathrm{ab}$ & $22.7 \mathrm{a}$ & $2.36 \mathrm{a}$ & $42.4 \mathrm{a}$ & $7.01 \mathrm{ab}$ & $16.4 \mathrm{ab}$ & $3.36 \mathrm{ab}$ & $63.5 \mathrm{a}$ & $8.27 \mathrm{a}$ \\
\hline $45 \%$ peanut shell compost & $25 \mathrm{bc}$ & $20.6 \mathrm{~b}$ & $2.25 \mathrm{a}$ & $41.3 \mathrm{a}$ & $8.67 \mathrm{a}$ & $15.0 \mathrm{bc}$ & $2.91 \mathrm{bc}$ & $67.4 \mathrm{a}$ & $8.29 \mathrm{a}$ \\
\hline $60 \%$ peanut shell compost & $29 \mathrm{a}$ & $18.7 \mathrm{c}$ & $2.00 \mathrm{ab}$ & $37.7 \mathrm{ab}$ & $6.21 \mathrm{bc}$ & $12.0 \mathrm{c}$ & $2.63 \mathrm{bc}$ & $50.8 \mathrm{bc}$ & $6.94 \mathrm{ab}$ \\
\hline $100 \%$ peanut shell compost & $19 \mathrm{~d}$ & $11.7 \mathrm{~d}$ & $1.58 \mathrm{bc}$ & $22.7 \mathrm{c}$ & $4.02 \mathrm{~d}$ & $6.5 \mathrm{~d}$ & $1.43 \mathrm{~d}$ & $39.6 \mathrm{c}$ & $5.77 \mathrm{~b}$ \\
\hline
\end{tabular}

Values followed by the same letters in each row and column are not significantly different at the 0.05 level (least significant difference)

Table 5 The effect of nutrient solution on plant growth, nutrient concentration in leaf and nutrient uptake (mg/pot) by plant

\begin{tabular}{|c|c|c|c|c|c|c|c|c|c|}
\hline \multirow{2}{*}{$\begin{array}{l}\text { Nutrient } \\
\text { solution }\end{array}$} & \multicolumn{9}{|c|}{ The growth factors of dracaena marginata } \\
\hline & $\begin{array}{l}\text { Leaf } \\
\text { number }\end{array}$ & $\begin{array}{l}\text { Height } \\
(\mathrm{cm})\end{array}$ & $\begin{array}{l}\text { Crown } \\
\text { diameter } \\
(\mathrm{cm})\end{array}$ & $\begin{array}{l}\text { Fresh weight } \\
\text { of leaf }(\mathrm{g})\end{array}$ & $\begin{array}{l}\text { Dry weight } \\
\text { of leaf }(\mathrm{g})\end{array}$ & $\begin{array}{l}\text { Fresh weight } \\
\text { of stem }(\mathrm{g})\end{array}$ & $\begin{array}{l}\text { Dry weight } \\
\text { of stem }(\mathrm{g})\end{array}$ & $\begin{array}{l}\text { Fresh weight } \\
\text { of root }(\mathrm{g})\end{array}$ & $\begin{array}{l}\text { Dry weight } \\
\text { of root }(\mathrm{g})\end{array}$ \\
\hline Without NS* & $17 \mathrm{~b}$ & $16.6 \mathrm{~b}$ & $1.65 \mathrm{~b}$ & $50.3 \mathrm{~b}$ & $6.52 \mathrm{a}$ & $9.77 \mathrm{~b}$ & $20.1 \mathrm{~b}$ & $27.2 \mathrm{~b}$ & $4.87 \mathrm{~b}$ \\
\hline With NS & $32 \mathrm{a}$ & $22.2 \mathrm{a}$ & $2.30 \mathrm{a}$ & $60.2 \mathrm{a}$ & $7.64 \mathrm{a}$ & $17.23 \mathrm{a}$ & $3.3 \mathrm{a}$ & $45.8 \mathrm{a}$ & $7.56 \mathrm{a}$ \\
\hline \multirow[t]{2}{*}{ Nutrient solutio } & \multicolumn{9}{|c|}{ Nutrient concentration in leaf } \\
\hline & \multicolumn{2}{|c|}{$\begin{array}{l}\text { Nitrogen } \\
(\%)\end{array}$} & $\begin{array}{l}\text { Phosphorus } \\
(\%)\end{array}$ & $\begin{array}{l}\text { Potassium } \\
(\%)\end{array}$ & $\begin{array}{l}\text { Calcium } \\
(\%)\end{array}$ & $\begin{array}{l}\text { Magnesium } \\
(\%)\end{array}$ & $\begin{array}{l}\text { Iron } \\
(\mathrm{mg} / \mathrm{kg})\end{array}$ & $\begin{array}{l}\text { Zinc } \\
(\mathrm{mg} / \mathrm{kg})\end{array}$ & $\begin{array}{l}\text { Manganese } \\
(\mathrm{mg} / \mathrm{kg})\end{array}$ \\
\hline \multicolumn{2}{|l|}{ Without NS } & $1.49 \mathrm{a}$ & $0.67 \mathrm{~b}$ & $1.86 \mathrm{~b}$ & $6.06 \mathrm{~b}$ & $1.25 \mathrm{a}$ & 278.6 a & $44.50 \mathrm{a}$ & $121.9 \mathrm{a}$ \\
\hline \multicolumn{2}{|l|}{ With NS } & $1.79 \mathrm{a}$ & $0.90 \mathrm{a}$ & $3.21 \mathrm{a}$ & $6.60 \mathrm{~b}$ & $1.42 \mathrm{a}$ & $278.4 \mathrm{a}$ & $27.89 \mathrm{~b}$ & $96.75 \mathrm{~b}$ \\
\hline \multirow[t]{2}{*}{ Nutrient solutior } & & \multicolumn{8}{|c|}{ Nutrient uptake (mg/pot) by plant } \\
\hline & \multicolumn{2}{|c|}{ Nitrogen } & Phosphorus & Potassium & Calcium & Magnesium & Iron & Zinc & Manganese \\
\hline \multicolumn{2}{|l|}{ Without NS } & $64.4 \mathrm{~b}$ & $29.6 \mathrm{~b}$ & $89.1 \mathrm{~b}$ & $290.4 \mathrm{~b}$ & $55.3 \mathrm{~b}$ & $1.34 \mathrm{~b}$ & $0.19 \mathrm{a}$ & $0.52 \mathrm{~b}$ \\
\hline \multicolumn{2}{|l|}{ With NS } & $133.9 \mathrm{a}$ & $57.4 \mathrm{a}$ & $236.1 \mathrm{a}$ & 491.9 a & 96.7 a & $1.94 \mathrm{a}$ & $0.20 \mathrm{a}$ & $0.72 \mathrm{a}$ \\
\hline
\end{tabular}

* Nutrient solution

significant at a $5 \%$ level. The interaction impact $\mathrm{A} \times \mathrm{B}$ was not significant only on $\mathrm{N}$ uptake at a $5 \%$ level. The results of Table 10 show that the highest nitrogen uptake $(162.1 \mathrm{mg} / \mathrm{pot})$ was obtained for the $15 \%$ peanut shell compost, which showed a significant difference from the 0 ,
30, 45, 60 and $100 \%$ treatments. The lowest uptake of nitrogen was observed for the $100 \%$ peanut shell compost $(53.27 \mathrm{mg} / \mathrm{pot})$. The control treatment had the highest phosphorus uptake $(70.28 \mathrm{mg} / \mathrm{pot})$, which did not show a significant difference from the $15 \%$ compost; however, 


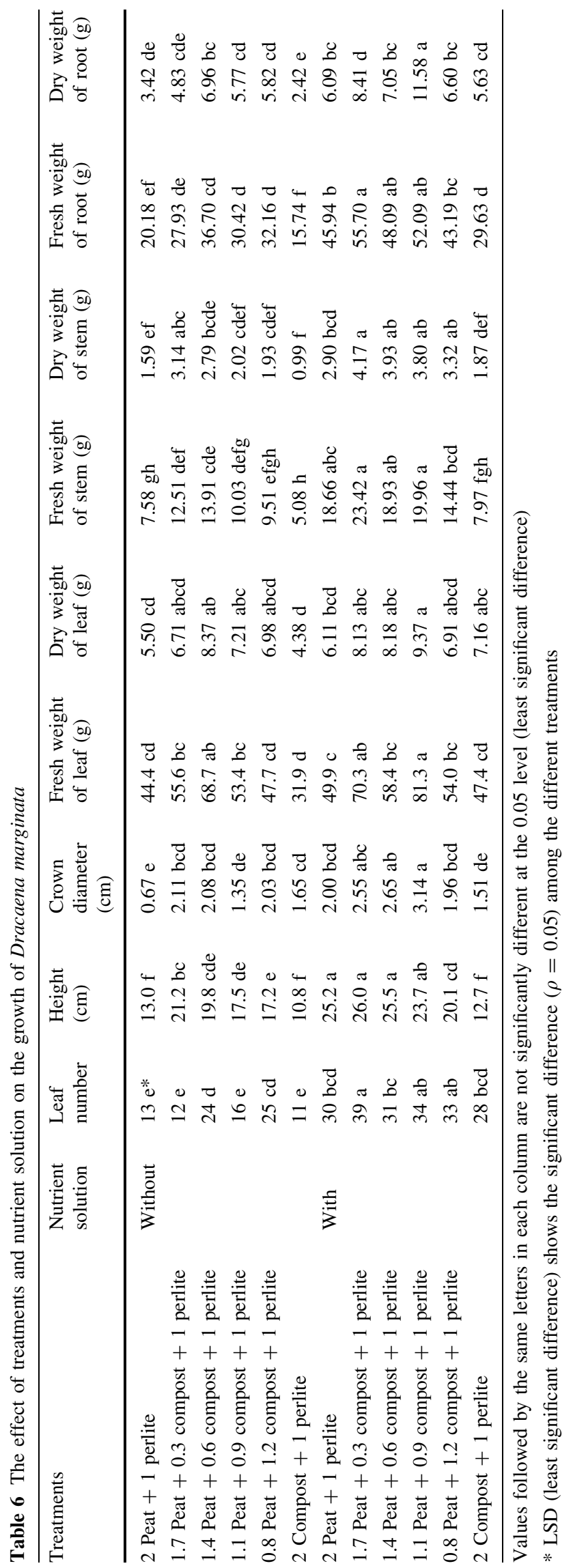

there was a remarkable difference with other peanut shell compost treatments. The highest and the lowest uptakes of potassium were, respectively, related to the 45 and $100 \%$ peanut shell compost. Potassium uptake in 15 and $30 \%$ of peanut shell compost treatments (182.6 and $185.0 \mathrm{mg} / \mathrm{pot}$, respectively) showed no significant difference from the control. The lowest calcium uptake was related to the $100 \%$ peanut shell compost, which showed no significant difference from the control. Manganese uptake increased significantly for the $15 \%$ compost compared to the control, but decreased significantly in other peanut shell compost treatments when compared with the control.

A nutrient solution significantly increased the uptake of $\mathrm{N}, \mathrm{P}, \mathrm{K}, \mathrm{Ca}, \mathrm{Mg}, \mathrm{Fe}$ and $\mathrm{Mn}$ compared to no nutrient solution (Table 5). Table 11 shows the interaction impact of $\mathrm{A} \times \mathrm{B}$ on the nutrient uptake by plants. The $15 \%$ compost treatment with a nutrient solution showed the best uptake of nutrients compared to the control. The control treatment with a nutrient solution had a better nitrogen, phosphorus potassium and magnesium uptake than the compost treatment without a nutrient solution.

\section{Discussion}

The total nitrogen increased in proportion to the peanut shell compost used. This may have been due to the increased nitrogen provided by composted peanut shells rather than peat. Grigatti et al. (2007) reported increasing nitrogen in pot cultivation beds by adding manure compost to the soil rather than peat. The nitrogen of cultivated beds was at a sufficient level for plant growth according to Nappi and Barberis (1993). The phosphorus decreased in proportion to the compost used (Grigatti et al. 2007). The highest and the lowest phosphorus for growth media was related to the control and the $100 \%$ treatment with peanut shell compost, respectively. The phosphorus levels for composted peanut shells were higher than for peat, but the available $\mathrm{P}$ of compost treatments decreased. It appeared that microorganisms had converted mineral $\mathrm{P}$ to organic $\mathrm{P}$ during organic matter mineralization, thereby temporarily decreasing the availability of phosphorus (Mohammadi Tarkashvand et al. 2005). Grigatti et al. (2007) and PrezMurcia et al. (2006) also reported a decrease in phosphorus of growth media containing green waste compost and sewage sludge. Meanwhile, there occurred a nutrient concentration and $\mathrm{C} / \mathrm{N}$ ratio change during the growth of plants and decomposition of organic matter in beds. Logakanthi et al. (2006) reported that the $\mathrm{C} / \mathrm{N}$ ratio of vegetable waste was reduced by $69 \%$ during composting, along with the consumption of $50 \%$ phosphorus by fungal species. Peanut shell compost increased the potassium levels of media in proportion to the compost used 
Table 7 The ANOVA results of the treatment effects on nutrient concentration in leaf and nutrient uptake by plant

\begin{tabular}{|c|c|c|c|c|c|c|c|c|c|}
\hline \multirow[t]{3}{*}{ Variation in resources } & \multirow[t]{3}{*}{ Freedom degree } & \multicolumn{8}{|c|}{ Mean squared } \\
\hline & & \multicolumn{8}{|c|}{ Nutrient concentration in leaf } \\
\hline & & Nitrogen & Phosphorus & Potassium & Calcium & Magnesium & Iron & Zinc & Manganese \\
\hline A: compost & 5 & $1.21 *$ & $1.98 *$ & $0.023^{\text {ns }}$ & $2.83 *$ & $20.5^{*}$ & $31683.5^{*}$ & $1153.3^{*}$ & $56607.6^{*}$ \\
\hline B: nutrient solution & 1 & $0.81^{\mathrm{ns}}$ & $0.45 *$ & $16.4 *$ & $2.67^{\mathrm{ns}}$ & $0.26^{\mathrm{ns}}$ & $0.38^{\mathrm{ns}}$ & $2483.3 *$ & $5680.6 *$ \\
\hline$A \times B$ & 5 & $0.16^{\mathrm{ns}}$ & $1.67 *$ & $0.51 *$ & $2.66^{*}$ & $3.02 *$ & $40086.0 *$ & $1122.9 *$ & $9268.3^{*}$ \\
\hline Error & 24 & 0.23 & 1.21 & 0.14 & 0.29 & 5.26 & 2273.2 & 93.9 & 484.1 \\
\hline \multirow[t]{3}{*}{ Variation in resources } & Freedom degree & \multicolumn{8}{|c|}{ Mean squared } \\
\hline & & \multicolumn{8}{|c|}{ Nutrient uptake by plant } \\
\hline & & Nitrogen & Phosphorus & Potassium & Calcium & Magnesium & Iron & Zinc & Manganese \\
\hline A: Compost & 5 & $7518.2 *$ & $3868.2 *$ & $11587.7 *$ & $51094.7 *$ & $5298.0 *$ & $0.936 *$ & $0.054 *$ & $1.34 *$ \\
\hline B: Nutrient solution & 1 & $38527.1^{*}$ & $6983.3 *$ & $194378.1 *$ & $365396.0^{*}$ & $15387.9 *$ & $3.22 *$ & $0.001^{\mathrm{ns}}$ & $0.34 *$ \\
\hline$A \times B$ & 5 & $1685.5^{\mathrm{ns}}$ & $3153.6^{*}$ & $2749.1^{*}$ & $19605.2 *$ & $5272.2 *$ & $1.44^{*}$ & $0.059^{*}$ & $0.067 *$ \\
\hline Error & 24 & 782.1 & 209.7 & 1849.5 & 9476.7 & 896.7 & 0.197 & 0.005 & 0.019 \\
\hline
\end{tabular}

* significant at $5 \%$ level

ns not significant at $5 \%$ level

Table 8 The effect of treatments on the nutrient concentration of leaf

\begin{tabular}{|c|c|c|c|c|c|c|c|c|}
\hline Treatment & $\begin{array}{l}\text { Nitrogen } \\
(\%)\end{array}$ & $\begin{array}{l}\text { Phosphorus } \\
(\%)\end{array}$ & $\begin{array}{l}\text { Potassium } \\
(\%)\end{array}$ & $\begin{array}{l}\text { Calcium } \\
(\%)\end{array}$ & $\begin{array}{l}\text { Magnesium } \\
(\%)\end{array}$ & $\begin{array}{l}\text { Iron } \\
(\mathrm{mg} / \mathrm{kg})\end{array}$ & $\begin{array}{l}\text { Zinc } \\
(\mathrm{mg} / \mathrm{kg})\end{array}$ & $\begin{array}{l}\text { Manganese } \\
(\mathrm{mg} / \mathrm{kg})\end{array}$ \\
\hline Control & $1.83 \mathrm{~b}$ & $1.61 \mathrm{a}$ & $2.65 \mathrm{a}$ & $6.39 \mathrm{~b}$ & $1.83 \mathrm{~b}$ & $341.7 \mathrm{a}$ & $27.8 \mathrm{~b}$ & $258.1 \mathrm{a}$ \\
\hline $15 \%$ peanut shell compost & $2.46 \mathrm{a}$ & $1.02 \mathrm{~b}$ & $2.57 \mathrm{a}$ & $6.29 \mathrm{~b}$ & $0.81 \mathrm{~cd}$ & $185.5 \mathrm{~b}$ & $48.9 \mathrm{a}$ & $204.2 \mathrm{~b}$ \\
\hline $30 \%$ peanut shell compost & $1.36 \mathrm{~b}$ & $0.49 \mathrm{~d}$ & $2.60 \mathrm{a}$ & $7.28 \mathrm{a}$ & $0.25 \mathrm{~cd}$ & $314.4 \mathrm{a}$ & $24.7 \mathrm{~b}$ & $74.2 \mathrm{c}$ \\
\hline $45 \%$ peanut shell compost & $1.27 \mathrm{~b}$ & $0.80 \mathrm{c}$ & $2.45 \mathrm{a}$ & $5.15 \mathrm{c}$ & $0.70 \mathrm{~cd}$ & $185.7 \mathrm{~b}$ & $28.4 \mathrm{~b}$ & $53.7 \mathrm{~cd}$ \\
\hline $60 \%$ peanut shell compost & $1.55 \mathrm{~b}$ & $0.33 \mathrm{e}$ & $2.46 \mathrm{a}$ & $6.29 \mathrm{~b}$ & $0.76 \mathrm{~cd}$ & $329.6 \mathrm{a}$ & $58.2 \mathrm{a}$ & $32.2 \mathrm{~d}$ \\
\hline $100 \%$ peanut shell compost & $1.35 \mathrm{~b}$ & $0.32 \mathrm{e}$ & $2.37 \mathrm{a}$ & $6.57 \mathrm{~b}$ & $2.76 \mathrm{a}$ & $313.9 \mathrm{a}$ & $29.2 \mathrm{~b}$ & $32.1 \mathrm{~d}$ \\
\hline
\end{tabular}

Values followed by the same letters in each row and column are not significantly different at the 0.05 level (least significant difference)

compared to the control (Grigatti et al. 2007). The amount of potassium in peanut shell compost was 50 times more than in peat, leading to an increase in the medium's potassium level.

The higher nitrogen and lower carbon levels of peanut shell compost compared to peat caused a decrease in the $\mathrm{C} / \mathrm{N}$ ratio of compost treatments (Gayasinghe et al. 2010). This ratio was lower than the allowed level, which is suitable for growing ornamental plants. Davidson et al. (1994) reported that the $\mathrm{C} / \mathrm{N}$ ratio of ideal compost was lower than 20 for growth of plants. A $\mathrm{C} / \mathrm{N}$ ratio of more than 30 may cause problems for plant growth (Zucconi et al. 1981). The $\mathrm{pH}$ values of the cultivation beds were at the optimum range for culturing ornamental plants, so according to Abad et al. (2001) the appropriate $\mathrm{pH}$ for desirable growth was determined as 5.3-6.5.

Some favorable factors in terms of beauty such as the size and appearance of the plant are the main criteria for determining ornamental plants' tolerance to salinity. The maximum allowed salinity level of saturation extract for Dracaena is 6-8 dS/m (Alizadeh 1999). Therefore, it is possible that salinity may cause some problems in the growth of plants with higher compost level. Grigatti et al. (2007) found that the $\mathrm{pH}$ and $\mathrm{EC}$ of cultivation beds increased by adding 25-100\% v/v green waste compost instead of peat to cultivation beds.

A comparison of the control treatment with a nutrient solution with compost treatments, but without a nutrient solution indicated that growth indices in the control treatment were approximately the same with compost treatments and without a nutrient solution. The growth of Dracaena includes height, leaf number, dry leaf weight and dry stem weight, which in $15,30,45$ and $60 \%$ compost were higher than in the control and in $100 \%$ peanut shell compost. It seems that the impact of peanut shell compost occurs due to the presence of humic materials; thus, Chen et al. (1989) claimed that the impact of compost on Ficus benjamina growth may be similar to the role of growth 
Table 9 The effect of treatments and nutrient solution on the nutrient concentration of leaf

\begin{tabular}{llllllllll}
\hline Treatments & $\begin{array}{l}\text { Nutrient } \\
\text { solution }\end{array}$ & $\begin{array}{l}\text { Total } \\
\text { nitrogen }\end{array}$ & Phosphorus & Potassium & Calcium & Magnesium & Iron & Zinc & Manganese \\
\hline 2 Peat +1 perlite & Without & $1.70 \mathrm{bc}$ & $2.13 \mathrm{a}$ & $1.80 \mathrm{~d}$ & $6.58 \mathrm{bcde}$ & $1.73 \mathrm{bc}$ & $442.4 \mathrm{a}$ & $25.01 \mathrm{c}$ & $345.4 \mathrm{a}$ \\
1.7 Peat +0.3 compost +1 perlite & & $2.18 \mathrm{ab}$ & $1.13 \mathrm{~b}$ & $1.73 \mathrm{~d}$ & $5.71 \mathrm{ef}$ & $0.73 \mathrm{de}$ & $195.2 \mathrm{bc}$ & $69.50 \mathrm{~b}$ & $225.7 \mathrm{~b}$ \\
1.4 peat +0.6 compost +1 perlite & & $1.04 \mathrm{c}$ & $0.52 \mathrm{~d}$ & $1.53 \mathrm{~d}$ & $5.83 \mathrm{dfe}$ & $1.08 \mathrm{~cd}$ & $374.7 \mathrm{c}$ & $26.86 \mathrm{c}$ & $53.10 \mathrm{e}$ \\
1.1 Peat +0.9 compost +1 perlite & & $1.17 \mathrm{c}$ & $0.07 \mathrm{f}$ & $2.14 \mathrm{~cd}$ & $5.17 \mathrm{f}$ & $0.67 \mathrm{de}$ & $208.7 \mathrm{bc}$ & $21.80 \mathrm{c}$ & $53.14 \mathrm{e}$ \\
0.8 Peat +1.2 compost +1 perlite & & $1.36 \mathrm{bc}$ & $0.10 \mathrm{ef}$ & $1.76 \mathrm{~d}$ & $6.67 \mathrm{bcd}$ & $1.09 \mathrm{~cd}$ & $246.6 \mathrm{~b}$ & $86.62 \mathrm{a}$ & $32.62 \mathrm{e}$ \\
2 Compost +1 perlite & & $1.50 \mathrm{bc}$ & $0.10 \mathrm{ef}$ & $2.18 \mathrm{~cd}$ & $6.38 \mathrm{bcde}$ & $2.20 \mathrm{~b}$ & $203.9 \mathrm{bc}$ & $37.23 \mathrm{c}$ & $21.27 \mathrm{e}$ \\
2 Peat +1 perlite & With & $1.97 \mathrm{abc}$ & $1.10 \mathrm{~b}$ & $3.33 \mathrm{ab}$ & $6.21 \mathrm{bcde}$ & $1.93 \mathrm{~b}$ & $241.0 \mathrm{bc}$ & $30.54 \mathrm{c}$ & $170.8 \mathrm{c}$ \\
1.7 Peat +0.3 compost +1 perlite & & $2.74 \mathrm{a}$ & $0.91 \mathrm{bc}$ & $3.41 \mathrm{ab}$ & $6.86 \mathrm{~b}$ & $0.90 \mathrm{de}$ & $175.8 \mathrm{bc}$ & $28.41 \mathrm{c}$ & $182.7 \mathrm{c}$ \\
1.4 Peat +0.6 compost +1 perlite & & $1.69 \mathrm{bc}$ & $0.47 \mathrm{de}$ & $3.68 \mathrm{a}$ & $8.74 \mathrm{a}$ & $1.41 \mathrm{bcd}$ & $254.1 \mathrm{~b}$ & $22.46 \mathrm{c}$ & $95.23 \mathrm{~d}$ \\
1.1 Peat +0.9 compost +1 perlite & & $1.38 \mathrm{bc}$ & $0.12 \mathrm{ef}$ & $2.67 \mathrm{bc}$ & $5.14 \mathrm{f}$ & $0.73 \mathrm{de}$ & $162.7 \mathrm{c}$ & $34.98 \mathrm{c}$ & $54.30 \mathrm{e}$ \\
0.8 Peat +1.2 compost +1 perlite & & $1.75 \mathrm{bc}$ & $0.56 \mathrm{~cd}$ & $3.16 \mathrm{ab}$ & $5.90 \mathrm{cdef}$ & $0.23 \mathrm{e}$ & $412.6 \mathrm{a}$ & $29.80 \mathrm{c}$ & $31.84 \mathrm{e}$ \\
2 Compost +1 perlite & & $1.20 \mathrm{c}$ & $2.23 \mathrm{a}$ & $2.90 \mathrm{~b}$ & $6.76 \mathrm{bc}$ & $3.32 \mathrm{a}$ & $424.0 \mathrm{a}$ & $21.16 \mathrm{c}$ & $45.56 \mathrm{e}$ \\
\hline
\end{tabular}

Table 10 The effect of treatments on the nutrient uptake (mg/pot) by plant

\begin{tabular}{|c|c|c|c|c|c|c|c|c|}
\hline Treatment & Nitrogen & Phosphorus & Potassium & Calcium & Magnesium & Iron & Zinc & Manganese \\
\hline Control & $89.4 \mathrm{~b}$ & $70.3 \mathrm{a}$ & $130.8 \mathrm{~cd}$ & $300.9 \mathrm{~cd}$ & $90.5 \mathrm{ab}$ & $1.49 \mathrm{~b}$ & $0.138 \mathrm{~b}$ & $1.08 \mathrm{~b}$ \\
\hline $15 \%$ peanut shell compost & $162.1 \mathrm{a}$ & 65.6 a & $185.0 \mathrm{ab}$ & $426.8 \mathrm{ab}$ & $55.1 \mathrm{~cd}$ & $1.22 \mathrm{~b}$ & $0.286 \mathrm{a}$ & $1.30 \mathrm{a}$ \\
\hline $30 \%$ peanut shell compost & $95.6 \mathrm{~b}$ & $35.6 \mathrm{~b}$ & $182.6 \mathrm{ab}$ & $509.6 \mathrm{a}$ & $87.5 \mathrm{abc}$ & $2.19 \mathrm{a}$ & $0.172 \mathrm{~b}$ & $0.52 \mathrm{c}$ \\
\hline $45 \%$ peanut shell compost & $109.8 \mathrm{~b}$ & $69.3 \mathrm{c}$ & $222.9 \mathrm{a}$ & $453.3 \mathrm{ab}$ & $61.8 \mathrm{bcd}$ & $1.51 \mathrm{~b}$ & $0.226 \mathrm{a}$ & $0.47 \mathrm{c}$ \\
\hline $60 \%$ peanut shell compost & $96.9 \mathrm{~b}$ & $21.3 \mathrm{bc}$ & $185.7 \mathrm{bc}$ & $388.9 \mathrm{bc}$ & $39.4 \mathrm{~d}$ & $2.07 \mathrm{a}$ & $0.348 \mathrm{a}$ & $0.20 \mathrm{~d}$ \\
\hline $100 \%$ peanut shell compost & $53.3 \mathrm{c}$ & $24.5 \mathrm{bc}$ & $98.9 \mathrm{~d}$ & $267.6 \mathrm{~d}$ & $121.8 \mathrm{a}$ & $1.37 \mathrm{~b}$ & $0.105 \mathrm{~b}$ & $0.15 \mathrm{~d}$ \\
\hline
\end{tabular}

Values followed by the same letters in each row and column are not significantly different at the 0.05 level (least significant difference)

regulators in plant. The growth of plants decreased significantly in the $100 \%$ peanut shell compost treatment due to the large number of pores and a decrease in waterholding capacity. Pool and Conover (1991) also reported the weak growth of dracaena grown in organic beds with a high pore presence and low water-holding capacity. The growth of dracaena in the control bed was low, so indexes such as leaf number and dry stem and leaf weight in this treatment showed no significant difference compared to $100 \%$ treatment with peanut shell compost. This may be due to the large $\mathrm{C} / \mathrm{N}$ ratio in the control bed and the decreased need for nitrogen of the plant, compared to the 15 , 30,45 and $60 \%$ treatments with peanut shell compost. Gayasinghe et al. (2010) used manure compost (CMC) and synthetic compounds (SA) as an alternative to peat in cultivating Tagetes paluta and concluded that plant height, the number of flowers for each plant, the dry and fresh weights of stems, root length and dry and fresh weights of roots increased in the combined treatment using $40 \% \mathrm{SA}$ and $60 \% \mathrm{v} / \mathrm{v} \mathrm{CMC}$.

The nutrient concentration in dracaena leaves was within the presented range as shown by Denis et al. (2003), denoting the effectiveness of nutrient range for plant growth. Lack of significant potassium level changes in treatments using peanut shell compost may be due to a higher yield of dry leaf matter in these treatments, compared to the control. In fact, potassium uptake occurred in plants, but the higher yield of plants and the dilution effect indicated no observable difference from the control. Additionally, in most cases, concentration variations did not follow from the values of these elements in the cultivation beds. In terms of nutrient concentration in plant organs, these depended on different factors such as plant growth, ionic competition and deposition; therefore, sometimes it is impossible to use nutrient concentrations in plants as a reliable parameter for assessing plant growth. The impact of nutrient dilution resulting in additional yields can also give rise to confusion. In this regard, nutrient uptake by plants from growth media is considered a more reliable parameter.

Increasing the amount of peanut shell compost (less than $60 \%$ ) caused an increase in nitrogen uptake by plants when compared with the control; this may have been due to the decomposed organic material in the substrate medium and as a result of increasing the amount of available nitrogen to plants. Increasing peanut shell 
Table 11 The effect of treatments and nutrient solution on the nutrient uptake (mg/pot) by plant

\begin{tabular}{|c|c|c|c|c|c|c|c|c|c|}
\hline Treatments & $\begin{array}{l}\text { Nutrient } \\
\text { solution }\end{array}$ & $\begin{array}{l}\text { Total } \\
\text { nitrogen }\end{array}$ & Phosphorus & Potassium & Calcium & Magnesium & Iron & Zinc & Manganese \\
\hline 2 Peat +1 perlite & Without & 59.0 ef & $66.7 \mathrm{a}$ & $59.9 \mathrm{fg}$ & $223.9 \mathrm{~cd}$ & 64.0 cde & $1.46 \mathrm{~cd}$ & $0.086 \mathrm{e}$ & $0.69 \mathrm{~b}$ \\
\hline 1.7 Peat +0.3 compost +1 perlite & & 100.9 cde & $54.6 \mathrm{ab}$ & $83.8 \mathrm{efg}$ & $276.0 \mathrm{bcd}$ & $35.6 \mathrm{de}$ & $0.95 \mathrm{de}$ & $0.24 \mathrm{~cd}$ & $1.08 \mathrm{~b}$ \\
\hline 1.4 Peat +0.6 compost +1 perlite & & $72.3 \mathrm{def}$ & $33.5 \mathrm{bc}$ & $105.2 \mathrm{efg}$ & $402.5 \mathrm{~b}$ & 74.9 bcd & $1.79 \mathrm{bc}$ & $0.16 \mathrm{de}$ & $0.37 \mathrm{~d}$ \\
\hline 1.1 Peat +0.9 compost +1 perlite & & $66.1 \mathrm{ef}$ & $4.1 \mathrm{~d}$ & 130.9 def & 298.9 bcd & $40.6 \mathrm{de}$ & $1.19 \mathrm{~cd}$ & 0.123 de & $0.31 \mathrm{~d}$ \\
\hline 0.8 Peat +1.2 compost +1 perlite & & $78.0 \mathrm{cdef}$ & $6.0 \mathrm{~d}$ & 102.7 efg & $388.9 \mathrm{~b}$ & $15.2 \mathrm{e}$ & $1.43 \mathrm{~cd}$ & $0.20 \mathrm{ab}$ & $0.19 \mathrm{de}$ \\
\hline 2 Compost +1 perlite & & $34.5 \mathrm{f}$ & $1.3 \mathrm{~d}$ & $52.5 \mathrm{~g}$ & $152.5 \mathrm{~d}$ & 53.3 cde & $0.38 \mathrm{e}$ & $0.09 \mathrm{e}$ & $0.05 \mathrm{e}$ \\
\hline 2 Peat +1 perlite & With & $119.8 \mathrm{bc}$ & 73.9 a & $201.7 \mathrm{bcd}$ & $377.9 \mathrm{bc}$ & $117.0 \mathrm{~b}$ & $1.52 \mathrm{~cd}$ & 0.19 de & $1.14 \mathrm{~b}$ \\
\hline 1.7 Peat +0.3 compost +1 perlite & & $223.2 \mathrm{a}$ & $76.6 \mathrm{a}$ & $286.2 \mathrm{a}$ & $577.7 \mathrm{a}$ & $74.6 \mathrm{bcd}$ & $1.49 \mathrm{~cd}$ & $0.33 \mathrm{bc}$ & $1.53 \mathrm{a}$ \\
\hline 1.4 Peat +0.6 compost +1 perlite & & $118.9 \mathrm{bc}$ & $37.8 \mathrm{~b}$ & $259.9 \mathrm{ab}$ & $616.8 \mathrm{a}$ & $100.1 \mathrm{bc}$ & $2.60 \mathrm{a}$ & $0.187 \mathrm{de}$ & $0.67 \mathrm{c}$ \\
\hline 1.1 Peat +0.9 compost +1 Perlite & & $153.3 \mathrm{~b}$ & $13.5 \mathrm{~cd}$ & $315.0 \mathrm{a}$ & $607.7 \mathrm{a}$ & $83.1 \mathrm{bcd}$ & $1.83 \mathrm{bc}$ & $0.41 \mathrm{ab}$ & $0.63 \mathrm{c}$ \\
\hline 0.8 Peat +1.2 compost +1 perlite & & $116.0 \mathrm{bcd}$ & $36.6 \mathrm{bc}$ & $208.6 \mathrm{bc}$ & $490.9 \mathrm{~b}$ & $63.6 \mathrm{cde}$ & $2.72 \mathrm{a}$ & $0.50 \mathrm{a}$ & $0.21 \mathrm{de}$ \\
\hline 2 Compost +1 perlite & & $72.0 \mathrm{def}$ & $17.8 \mathrm{~cd}$ & 145.3 cde & $382.7 \mathrm{bc}$ & $140.2 \mathrm{a}$ & $2.36 \mathrm{ab}$ & $0.12 \mathrm{e}$ & $0.25 \mathrm{de}$ \\
\hline
\end{tabular}

compost caused a decrease in the $\mathrm{C} / \mathrm{N}$ ratio when compared with the control. This process was also reported by Oworu et al. (2010), so an increase in the uptake of nitrogen by the plant was observed when compost was added to the growth medium of an Amaranthus ornamental plant.

The increasing amount of peanut shell compost decreased phosphorus uptake in leaves in comparison to the control (compost more than $15 \%$ ). It appears that microorganisms converted mineral $\mathrm{P}$ to organic $\mathrm{P}$ during organic matter mineralization, thereby temporarily decreasing the availability of phosphorus (Mohammadi Tarkashvand et al. 2005). The lowest phosphorus uptake was obtained in the $45 \%$ compost treatment. This may have been due to the dilution effect, because of the larger size of the plant and a decreasing $\mathrm{P}$ concentration. Grigatti et al. (2007) also reported a decrease of phosphorus uptake by mimulus and salvia plants in beds containing green waste compost and sewage sludge when compared with controls (white peat).

Increasing $\mathrm{K}$ uptake in compost treatments is due to an increase in the availability of potassium in media by addition of peanut shell compost. Calcium uptake increased in compost treatments due to the higher yield of these treatments, compared to the control. The decrease in $\mathrm{Ca}$ uptake in the $100 \%$ compost treatment was due to the lower yield of plant than in the control. Manganese uptake increased in $15 \%$ compost and then decreased in other treatments of peanut shell compost in proportion to the applied compost. This increase was due to the higher yield of plants when compared with the control, while the subsequent decrease was due to the decreasing Mn concentration in leaves (Mn concentration in leaves was 258.1, $204.2,74.2,53.7,32.2$ and $32.1 \mathrm{mg} / \mathrm{kg}$, respectively, in the control and 15, 30, 45, 60 and $100 \%$ of plants with peanut shell compost). Magnesium uptake decreased in compost treatments compared to the control, whereas it increased in the $100 \%$ compost treatment. This may have been due to ionic competition and the interaction effect between $\mathrm{Ca}$ and $\mathrm{Mg}$. The increase of $\mathrm{Fe}$ uptake in 30 and $60 \%$ compost treatments, compared to the control, was due to the higher yield of plants with these treatments. The highest zinc uptake was observed for the $60 \%$ compost treatment, which may have been due to the higher concentration of $\mathrm{Zn}$ in the shoots of plants compared to other treatments $(58.21 \mathrm{mg} / \mathrm{kg})$.

\section{Conclusion}

Peanut shells as wastes of peanut have a considerable volume in Guilan Province, Iran, the compost of which can be used as a cheap and accessible resource in the growth medium of ornamental plants. Peanut shell compost because of its favorable properties and high porosity can be mixed with low-porosity substrates and applied as a substitute to peat in the cultivation media. Increase in peanut compost level as 60 and $100 \%$ replacement is not suggested. Investigation of the effects of peanut shell compost on the growth of other varieties of ornamental plants has been proposed.

Acknowledgments The authors would like to thank the Islamic Azad University, Rasht Branch, for the use of equipment and also Mr. Mahboob Khomami for his assistance.

Open Access This article is distributed under the terms of the Creative Commons Attribution License which permits any use, distribution, and reproduction in any medium, provided the original author(s) and the source are credited. 


\section{References}

Abad M, Noguera P, Bures S (2001) National inventory of organic wastes for use as growing media for ornamental potted plant production: case study in Spain. Bioresour Technol 77:197-200

Agriculture Organization of Guilan Province (2010) Crops data of Guilan province, Rasht, Iran

Alizadeh A (1999) Soil-water-plant relationships. Astan-e- Qods Razavi Press, 355 p (In Persian)

Atieyh RM, Arancon N, Edwars CA, Metzger JD (2000) Influence of earthworm processed pig manure on the growth and yield of greenhouse tomatoes. Bioresour Technol 75:175-180

Bugbee JG (2002) Growth of ornamental plants in container media amended with biosolids compost. Compos Sci Utilz 10:92-98

Chen Y, Inbar Y, Hadar Y (1989) Composted agricultural wastes as potting media for ornamental plants. Soil Sci 145:298-303

Cull DC (1981) Alternatives to peat as container media: organic resources in UK. Acta Hort 126:69-81

Davidson H, Mecklenburg R, Peterson C (1994) Nursery management: administration and culture, 3rd edn. Prentice Hall, Englewood Cliffs

Dennis B, Chen J, Richard J, Kelly C (2003) Cultural guidelines for commercial production of interiorscape Dracaena. University of Florida. URL at http://edis.ifas.ufl.edu. Accessed 24 May 2012

Edward F (1999) Dracaena Marginata. Environmental horticulture department, Institute of Agricultural Sciences. University of Florida, Gainesville, 32611

Fred DR, Hariss HM, Watanabe R, Stanley RW (1997) Plant growth in potting media using compost. Horticulture Research Note. University of Hawaii. pp 4

Gabriels R, Kerrsbulkand WV, Engels H (1993) A rapid method for the determination of physical properties of growing media. Acta Hort 342:243-247

Gayasinghe GY, Liyana Arachchi ID, Tokashiki Y (2010) Evaluation of containerized substrates developed from cattle manure compost and synthetic aggregates for ornamental plant production as a peat alternative. Resour Conserv Recycl 54:1412-1418

Grigatti M, Giorgioni ME, Ciavatta C (2007) Compost-based growing media: influence on growth and nutrient use of bedding plants. Bioresour Technol 98:3526-3534

Krumfolz LA, Wilsonand SB, Stoffella PJ (2000) Use of compost as a media amendment for containerized production of perennial cat whiskers. SNA Res Conf 45:69-72

Logakanthi S, Rajesh Banu J, Esakkiizaj JS, Vijayalakshmi GS (2006) Fungal composting- a novel method for green waste composting. Asian J Microbiol Biotechnol Environ Sci Paper 8(2):205-208

Maiti R, Ebeling W (2002) The peanut (Arachis hypogaea) crop. Science Pup., Inc., p 376
Mohammadi Tarkashvand A, Kalbasi M, Shariatmadari H (2005) Effects of converter slag on some chemical characteristics of acid soils. J Crop Prod Process 8(4):47-62

Mohammadi Torkashvand A (2010) Improvement of compost quality by addition of some amendments. Aust J Crop Sci 4(4):252-257

Murata M R (2003) The impact of soil acidity amelioration on groundnut production on sandy soils of Zimbabwe. Ph.D. Thesi, Uuniversity of Pretoria, Zimbabwe

Nappi P, Barberis R (1993) Compost as growing medium: chemical, physical and biological aspects. Acta Hort 342:249-256

Oworu OO, Dada OA, Majekodunmi OE (2010) Influence of compost on growth, nutrient uptake and dry matter partitioning of grain amaranths (Amaranthus hypochondriacus L.). Libyan Agr Res Center J Int 1(6):375-383

Papafotiou M, Phsyhalou M, Kargas G, Chatzipavlidis I, Chronopoulos J (2005) Olive-mill waste compost as growth medium component for the production of poinsettia. Hort Sci 102:167-175

Perez-Murcia MD, Moral R, Moreno-Caselles J, Perez-Espinosa A, Paredes C (2006) Use of composted sewage sludge in growth media for broccoli. Bioresour Technol 97:123-130

Pool RT, Conover CA (1991) Potential for eucalyptus mulch used as a component of potting mixes for foliage plant production. University of Florida, IFAS, Central Florida Research and Education Center - Apopka, CFREC-Apopka Research Report, RH-91-13

Rajesh Banu J, Logakanthi S, Vijayalakshmi GS (2001) Biomanagement of paper mill sludge using indigenous (Lampito mauritii) and two exotic (Edrilus eugineae and Eisenia foetida) earthworms. J Environ Biol 22(3):181-185

Rajesh Banu J, Raj E, Kaliappan S, Beck D, Yeom IT (2007) Solid state biomethanation of fruit wastes. J Environ Biol 28(4):741-745

Scharpenseel HW, Kunth K (1987) Use and importance of Azolla Anabaena in industrial countries, Azolla utilization (IRRI): 241-245

Singh R, Pradhan K (1981) Determination of nitrogen and protein by Kjeldahl method. In: Forage Evaluation Science. Pvt. Publishers Ltd., New Delhi, p 23

Verdonck O, Gabriels R (1992) Part I reference method for the determination of physical properties of plant substrates. Part II reference method for the determination of chemical properties of plant substrates. Acta Hort 302:169-179

WalkeyJA Black JA (1934) Estimation of organic carbon by the chromic acid titration method. Soil Sci 37:29-31

Zucconi F, Pera A, Forte M, Bertoldi M (1981) Evaluating toxicity of immature compost. Biol Cycle 22:54-57 